\title{
SOURCE, CHEMISTRY, METABOLISM, PHYSIOLOGICAL FUNCTION: ASCORBIC ACID WITH HUMAN HEALTH
}

\author{
Sharma Prashansa*, Sharma Pramod Kumar, Mishra Vidya Bhushan, Akanksha Bhandari \\ Department of Pharmacy, School of Medical and allied sciences, Galgotias University, Greater Noida, U. P. (India) \\ *Corresponding Contact-9310179107,E-mail-prashansa51@gmail.com
}

\begin{abstract}
Ascorbic acid commonly known as Vitamin C and it is water soluble vitamin having Antioxidant characteristics, abound in nature and highly labile.it is very important Vitamin for biosynthesis of collagen, carnitine and neurotransmitters. Some plants and animals synthesised this Vitamin but human, apes and some other are not able to synthesis this Vitamin due to lack of Gulonolactone oxidase enzyme. So, this Vitamin is supplemented by outer source like fruit, vegetable and synthetic pharmaceutical products. The current US recommended dietary allowances (RDA) for Ascorbic acid is 100-120 mg/day. Ascorbic acid has many biochemical functions like Antioxidant, Anti-antherogenic, Anti-carcinogenic, immunodulator and its preventing cold. It's also associated with reduction of incidence of cancer, immunity, blood pressure, drug metabolism and urinary hydroxyproline excretion, tissue regeneration. Mainly it shows effective result in gastric cancer. Ascorbic acid decreases the death risk. Now day, This Vitamin is used in nutraceutical in human biology and health.
\end{abstract}

Keywords: Ascorbic acid, Gulonolactone oxidase, antiantherogenic.

\section{INTRODUCTION}

Ascorbic acid is also known as Vitamin C. It is one of the most important water soluble vitamin. Vitamin $\mathrm{C}$ plays a key role in functioning of human body. It is essential for collagen, carnitine and neurotransmitters biosynthesis ${ }^{1}$.

Ascorbic acid is required for collagen synthesis. Collagen is the main constituent of structural protein network in connective tissues and it is most abundant protein in mammals ${ }^{2}$. Vitamin $\mathrm{C}$ plays a vital role in maintenance of collagen framework in human being or Anti-scurvy properties by preventing then autoinactivation of lysyl and proly hydroxylase enzyme in collagen biosynthesis. In addition to collagen formation it should have another important biological function, including copper and iron reduction (which facilitate iron absorption), carnitine biosynthesis. Vitamin $\mathrm{C}$ is also important for biosynthesis of neurotransmitter, some hormones and helps in metabolism process in human body which provide strength to the body. It also helps to body in detoxification of liver, protect blood to sever infections, increase the immunity power of the body by work as a reducing agent, to quench free radicals which provide optimal health and defence of tissues against the oxidative challenges associated with chronic disease and reduce inflammatory reactions in body. And the most important Antioxidant property is associated with reduction of cancer incidence ${ }^{3}$.

Almost plants and animals (mammals) synthesizes Ascorbic acid for their own requirement but apes and humans cannot synthesized Vitamin $\mathrm{C}$ due to lack of an enzyme L- Gulonolactone oxidase, because the gene encoding for the enzyme has undergone substantial mutation so that no protein is produced 4 . Hence, in human it should be supplemented by fruits, Vegetables and through medicines 5 . The current US recommended daily allowance (RDA) for Ascorbic acid ranges between $100-120 \mathrm{mg} /$ day for adults.

Ascorbic acid functioning in body as antioxidant, anticarcinogenic (only helpful in gastric cancer), antiatherogenic, immunomodulator and prevent common cold etc. It performs cellular reactions and processes. Epidemiological data now point to reduction of colds with increased consumption of food rich in Vitamin C ${ }^{6}$.Its help to maintain good health and increase blood Vitamin C levels which decrease the risk of death form in all conditions ${ }^{7}$.

According to recent studies on Ascorbic acid and salts of Ascorbates not clear it should be beneficial for all different type of cancer except one gastric cancer. In regular use some salt of Ascorbic acid like Sodium ascorbate in multivitamin tablets or capsules creates cancerous cell but on place this salt Potassium, Magnesium, Calcium and Ascorbic acid ester showed the anticancer activities. To understand all these activities of Ascorbic acid in-vivo studies are important and they should gave beneficial report of Ascorbic acid.

\section{HISTORICAL PERSPECTIVES}

Scurvy is a disease which is caused by deficiency of Vitamin $\mathrm{C}$ in body. Deficiency should be creating by not taking perishable items, fresh fruits and vegetables in daily diet. 
A British naval physician Lind in $1753^{8}$ documented that in citrus fruits some substance is present which cure scurvy. He developed the method to preserve citrus juice for longer use. Ascorbic acid was first isolated in 1930 from natural sources and structurally characterized by Szent-Gyorgyi, Waugh and King ${ }^{9-10}$. Ascorbic acid
(Vitamin C) was first synthesized by Haworth and Hirst $1933^{11}$.

\section{SOURCE OF ASCORBIC ACID}

Ascorbic acid widely present in nature, mostly found in fresh fruits and vegetables.

Table 1: Example of Ascorbic acid containing fruits and vegetables

\begin{tabular}{|c|c|c|c|}
\hline $\begin{array}{c}\text { FRUITS HAVE } \\
\text { ASCORBIC ACID }\end{array}$ & $\begin{array}{c}\text { ASCORBIC ACID } \\
\text { (mg/100g) }\end{array}$ & $\begin{array}{c}\text { VEGETABLES HAVE } \\
\text { ASCORBIC ACID }\end{array}$ & $\begin{array}{c}\text { ASCORBIC ACID } \\
\text { (mg/100g) }\end{array}$ \\
\hline Apple & $5 \mathrm{mg}$ & Broccoli & $60 \mathrm{mg}$ \\
Black currant & $200 \mathrm{mg}$ & Brussels sprouts & $100 \mathrm{mg}$ \\
Cherries & $48 \mathrm{mg}$ & Cabbage & $60 \mathrm{mg}$ \\
Grapes & $40 \mathrm{mg}$ & Carrots & $70 \mathrm{mg}$ \\
Guava & $100 \mathrm{mg}$ & Cauliflower & $30 \mathrm{mg}$ \\
Lemon & $50 \mathrm{mg}$ & Green bell pepper & $15 \mathrm{mg}$ \\
Mango & $30 \mathrm{mg}$ & Lettuce & $25 \mathrm{mg}$ \\
Orange & $50 \mathrm{mg}$ & Peas & $25 \mathrm{mg}$ \\
Papaya & $10 \mathrm{mg}$ & Potatoes & $70 \mathrm{mg}$ \\
Pineapple & $20 \mathrm{mg}$ & Red bell pepper & $15 \mathrm{mg}$ \\
Raspberries & $38 \mathrm{mg}$ & Spinach & $20 \mathrm{mg}$ \\
Strawberries & $45 \mathrm{mg}$ & Tomatoes & \\
Watermelon & $30 \mathrm{mg}$ & & \\
\hline
\end{tabular}

Animal source of Ascorbic acid like fish, meat, poultry, eggs, dairy products not contain significant amount they comprise smaller amount of Vitamin C. It is very labile molecule and lost during preparation, cooking, storage.

To prevent the loss of Vitamin C

- Take raw form of fruits and vegetables.

- Steam or boil the food for short time.
All plants and animals synthesis Ascorbic acid by Dglucose or D- glalactose and in animals this phenomenon is done in liver.

Synthetic Ascorbic acid is available in a wide variety of supplements like, tablets, capsules, chewable tablets, crystalline powder, effervescent tablets and liquid form.

A procedure for prepare synthetic L- Ascorbic acid

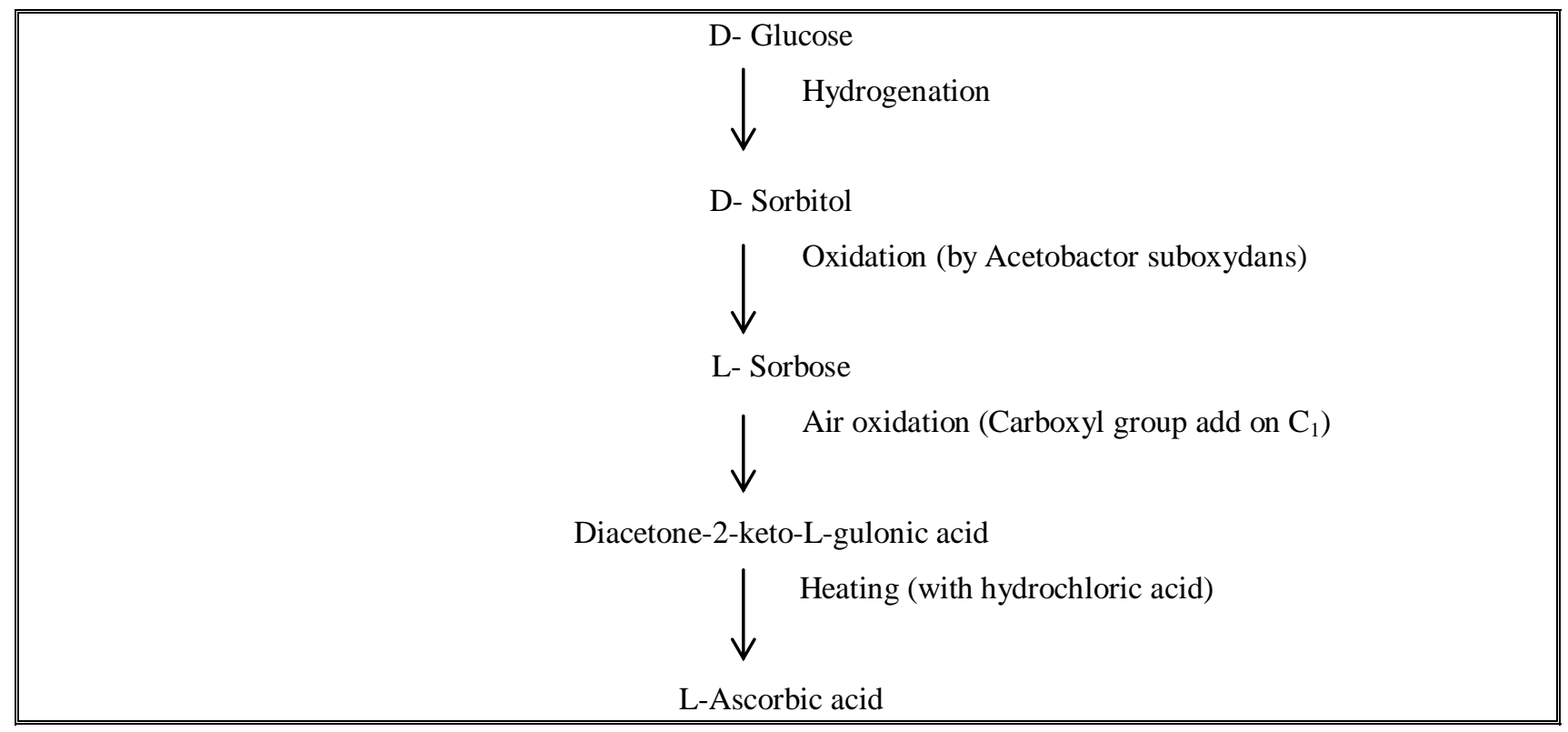

Figure 1: Synthetic L-Ascorbic acid in laboratory 


\section{CHEMISTRY OF ASCORBIC ACID}

Ascorbic acid is commonly found in L-(+)-Ascorbic acid. Its synonym is Vitamin C. Its empirical formula is $\mathrm{C}_{6} \mathrm{H}_{8} \mathrm{O}_{6}$ and molecular mass is $176.12 \mathrm{~g} / \mathrm{mole}$.

Structural formula:<smiles>O=C1O[C@@](C(O)O)([C@H](O)CO)C(O)=C1O</smiles>

Chemical name: 2-oxo-1-threo-hexone-1, 4-lactone-2, 3enediol or R-3, 4-dihydroxy-5-\{(s)-1, 2-dihydroxyethyl $\}$ furan $2(5 \mathrm{H})$ one.

It is highly reducing agent this chemical behaviour of Ascorbic acid is due to enediol structure conjugated with a carbonyl group (a lactone) which make this very sensitive to different ways of degradation.

\section{METABOLISM OF ASCORBIC ACID}

Ascorbic acid is an electron donor (antioxidant) this function of this preform all type of biochemical and molecular role in body. It should be easily available through the different source of food which is important for human diet and easily absorbed by the active transport system in the intestine ${ }^{12}$.

In normal required amount it should be easily absorbed in body about $80-85 \%$ but it cannot be store in body. If its quantity increases the rate of absorption rapidly declines and. Ascorbic acid is not protected for long time because it is very sensitive to air, temperature, light and moisture. By all these factors its shows maillard degradation reaction and organoleptic properties of Vitamin C changed.

The major metabolites of Ascorbic acid are dehydroascorbic acid, 2, 3 diketogluconic acid and oxalic acid. The main route of elimination of Ascorbic acid is renal through urine.

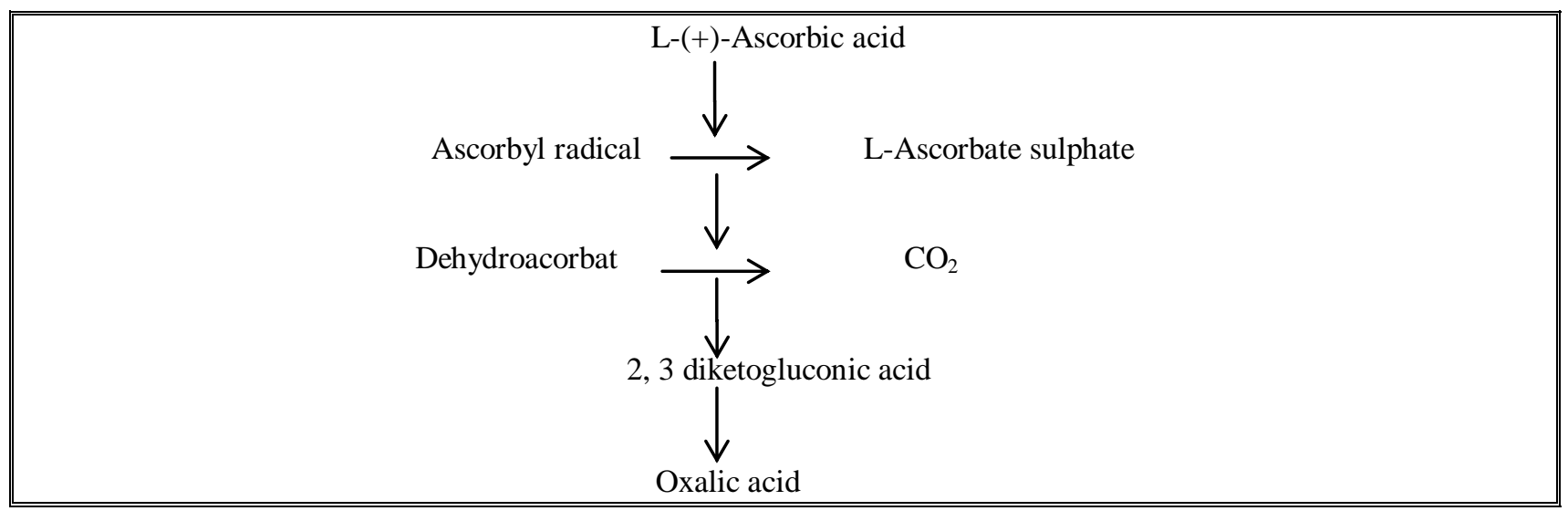

Figure 2: Catabolic pathway of Ascorbic acid

\subsection{Pharmacokinetic data}

Bioavailability- Rapid and complete

Protein binding- Negligible

Half-life- Varies according to plasma concentration

Excretion- Renal

Ascorbic acid deficiency leads to scurvy. It is characterized by spongy swollen bleeding gums, dry skin, and open sores on the skin, fatigue, impaired wound healing and depression ${ }^{13}$.

\section{DIETARY RECOMMENDATION OF ASCORBIC ACID}

The average intake level of Ascorbic acid is assumed because no one knows the actual level of it and it should be given in Table 2:

Table 2: The average intake level of Ascorbic acid:

\begin{tabular}{|c|c|}
\hline INFANT & CHILDREN \\
\hline $0-5-25 \mathrm{mg} /$ day & $1-3-30 \mathrm{mg} / \mathrm{day}$ \\
$6-11-30 \mathrm{mg} /$ day & $4-6-30 \mathrm{mg} / \mathrm{day}$ \\
& $7-9-35 \mathrm{mg} / \mathrm{day}$ \\
\hline ADOLESCENT & ADULTS \\
\hline $10-18$-boys-65mg/day & $19-65-$ Men-70mg/day \\
$10-18$-girls-65mg/day & $19-65$-Women-70mg/day \\
\hline ELDERS & OTHERS \\
\hline$>65-$ Men- $70 \mathrm{mg} /$ day & Pregnant Women- $80 \mathrm{mg} /$ day \\
\hline
\end{tabular}


Consumption of $100 \mathrm{mg} /$ day of Ascorbic acid is sufficient to saturate the body pool (neutrophils, leukocytes and other tissues) in every individual. Based on clinical and epidemiological studies it has been suggested that a dietary intake of $100 \mathrm{mg} /$ day of Ascorbic acid is associated with reduced incidence of mortality form heart diseases, stroke and cancer ${ }^{14}$. Some other factors are also responsible for decline in blood level of Ascorbic acid like-Stress, smoking, alcoholism, fever, viral infections. Smoking is known to increase the metabolic turnover of Ascorbic acid due to its oxidation by free radicals and reactive oxygen species generated by cigarette smoking ${ }^{15}$. It has been suggested that a daily intake of at least $140 \mathrm{mg} /$ day is required for smokers to maintain a total body pool similar to that of nonsmokers consuming $100 \mathrm{mg} /$ day $^{16}$.

\section{PHYSIOLOGICAL FUNCTIONS OF ASCORBIC ACID}

The Physiological functions of Ascorbic acid is totally depends on redox property of Vitamin. This Vitamin is the co-factor for hydroxylases and monoxygenase enzyme involved in the synthesis of collagen, caritine and neurotransmitters ${ }^{17}$. Ascorbic acid is also important for maintain the enzyme prolyl and lysyl hydroxylase. Its deficiency results in reduced hydroxylation of proline and lysine, thus affecting collagen synthesis.

Ascorbic acid is essential for the synthesis of muscle carnitine ( $\beta$-hydroxy butyric acid) ${ }^{18}$. Carnitine is used for energy production through fatty acid into mitrochondria.In addition; Ascorbic acid catalyzes other enzymatic reactions involving amidation necessary for maximal activity of hormones oxytocin, vasopressin, cholecystokinin and alpha-melanotripin ${ }^{19}$. Deficiency of Ascorbic acid is also cause cholesterol gall stones.

\section{ASCORBIC ACID WITH HEALTH}

Ascorbic acid always is used for health related benefits. It should be used in many health regarding problems.

Vitamin C largely prevents common cold. Pauling ${ }^{20}$ suggested that ingestion of 1-2 $\mathrm{g}$ of ascorbic acid effectively prevents common cold. In common cold Vitamin $C$ increase the immunity power of body and shows the prevented effects.

Ascorbic acid is responsible for biosynthesis of Collagen and shows key role in wound repairing/Regeneration process.

\section{REFERENCES}

1. Grudpan K, Kamfoo .K, Jakmunee .J, Flow injection spectrophotometric or conductometric determination of ascorbic acid in a vitamin $\mathrm{C}$ tablet using permanganate or ammonia ,Talanta, 1999, 49 (5), 1023-1026

2. Di lullo, Gloria A, Sweeney, Shawn M, Korkko, Jarmo, AlaKokko, Leena and San Antonio, James D, Mapping the ligand binding sites and Disease associated Mutations on the most Abundant protein in the human, Type 1 collagen, J. Bio. Chem, 2002, 277(6), 4223-4231

3. Lupulescu A, Hormones and vitamins in cancer Treatment, CRC 2. Press, BOCA Ration, Boston, 1990, 149-211.

4. Nishikimi $\mathrm{M}$ et al, Cloning and chromosomal mapping of the human non-functional gene for L-gulono-gamma-lactone oxidase, the enzyme for L-Ascorbic acid Biosynthesis missing
Cancer is worldwide problem which is faced in all over the world. Vitamin $\mathrm{C}$ is generally used in many types of cancer. Vitamin $\mathrm{C}$ is effective in protecting against oxidative damage in tissues and also suppresses formation of carcinogens like nitrosamine ${ }^{21}$. Many studies have shown that Vitamin $\mathrm{C}$ intake is inversely related to cancer, with protective effects shown for cancer of the lung, breast, pancreas, stomach, cervix, rectum and oral cavity 22 .

Lipid peroxidation and oxidative modification of low density lipoproteins (LDL) are implicated in development of atherosclerosis ${ }^{23}$. Vitamin $\mathrm{C}$ protect against oxidation of isolated LDL by different types of oxidative stress, including metal ion dependent and independent processes ${ }^{24}$. Addition of iron to plasma devoid of Ascorbic acid resulted in lipid peroxidation, whereas endogenous and exogenous Ascorbic acid was found to inhibit the lipid oxidation in iron-over loaded human plasma ${ }^{25}$. Similarly, when ascorbic acid was added to human serum supplemented with $\mathrm{Cu} 2+$, antioxidation activity rather than pro-oxidation effects were observed $^{26}$.

\section{CONCLUSION}

Ascorbic acid is the important and most essential Vitamin for living organism. It's vital for many physiological functions in human biology. Vitamin $\mathrm{C}$ is found from the fresh fruits, vegetables and other synthetic pharmaceutical products, and it important for maintain the body pool. But some important factors are important for depletion of Ascorbic acid like- stress, smoking, infections etc. According to RDA-100$120 \mathrm{mg} /$ day is required for achieve cellular saturation and optimum risk reduction of heart diseases, stoke and cancer in healthy individuals. Some where it is used as preservatives in food industry.

Thus, Ascorbic acid discovered in $17^{\text {th }}$ century, and it is important for human health and diseases.

\section{ACKNOWLEDGEMENT}

Authors are highly thankful to Department of Pharmacy, School of Medical and Allied Sciences, Galgotias University, Greater Noida India for providing library facility during literature survey.

CONFLICT OF INTEREST-Authors have no conflict of interest.

in man, Journal of biological chemistry, 1994, 269: 1368513688.

5. Skoog D.A, West D.M, Holler F.J, Fundamentals of Analytical Chemistry, seventh edition, Saunders college publishing, 1996.

6. Lupulescu A, The role of Vitamin A, B carotene, E and C in cancer cell Biology. Intern. Vit. Nutr. Res., 1993, 63, 3-14.

7. Gorton H.C, $\mathrm{K}$ Javis, The effectiveness of Vitamin $\mathrm{C}$ in preventing and relieving the symptoms of virus-induced Respiratory Infection, J. Man Phys. Ther, 1999, 22(8), 530533.

8. Lind J, A treatise of scurvy. Printed by sands, Murray and Cochran for Kincaid, A and Donaldson, A. Edinburgh 1753, 7,191-193. 
9. Svirbely J.L, Szent-Gyorgyi A, The chemical Nature of Vitamin C, Bio chem J, 1932, 26, 865-870

10. Waugh W A, King CG, Isolation and identification of Vitamin C, J Bio Chem, 1932, 97, 325-331

11. Haworth W N, Hirst E L, Synthesis of Ascorbic acid, J Soc Chem Ind ( London) 1933, 52, 645-647

12. Sauberlich H E, Bioavailability of vitamins, Prog food Nutr Sci, 1985, 9, 1-33.

13. Olson R E, Water soluble vitamins, in principles of Pharmacology, Edited by Munson PL, Mueller RA, Bresse GR. Chapman and Hall, New York; 1999: Chapter 59.

14. Carr A C, Frei B, Dose vitamin C act as pro-oxidant under physiological conditions, FASEB J, 1999, 13, 1007-1024.

15. Frei B, Forte T M, Ames B N, Cross C E, Gas-phase oxidants of cigarette smoke induce lipid peroxidation and changes in lipoprotein properties in human blood plasma: protective effects of Ascorbic acid, Bio chem J, 1981, 277, 133-138.

16. Kallner A, Hartmann D, Hornig D, On the requirement of Ascorbic acid in man: steady-state turnover and body pool in smokers, Am J Clin Nutr ,1981, 34, 1347-1355.

17. Levin $\mathrm{M}$, New concepts in the biology and biochemistry of Ascorbic acid, New Engl J Med, 1986, 31, 892-902.

18. Hulse J D, Ellis S R, Henderson L M, Carnitine biosynthesisbeta hydroxylation of trimethyllysine by $\alpha$-ketoglutarate dependent mitochondrial dioxygenase, J Biol. Chem, 1978, 253(5), 1654-1659.

19. Cameron E, Pauling L, Ascorbic acid and the glycosaminoglycans, Oncology [Pub.med]. 1973, 27(2), 181192.

20. Drake I M, Davies M J, Mapstone N P, Dixon M F, Schorah C J, White K L, Chamers D M, Axon A T, Ascorbic acid may protect against human gastric cancer by scavenging mucosal oxygen radicals, Carcinogenesis 1996, 17, 559-562.

21. Simon J A, Hudes E S and Tice J A, Relation of serum Ascorbic acid to Mortality among Adults, J. Am. Col. Nutr, 2001, 20 (3), 255-263.

22. Rock C L, Michael C W, Reynolds R K, Ruffin M T: Prevention of Cervix cancer, Crit Rev Oncol Hematol, 2000, $33,169-183$

23. Frei .B, Vitamin $\mathrm{c}$ as an antiatherogen: mechanism of action. In In Vitamin $\mathrm{C}$ in health and disease. Edited by packer L, Fuchs J. Marcel and Dekker, Inc., New York; 1997; 163-182.

24. Berger T M, Polidori M C, Dabhag A, Evans P J, Halliwell B, Marrow J D, Roberts L J, Frei B, Antioxidant activity of Vitamin $\mathrm{C}$ in iron-over loaded human plasma, J Biol Chem 1992, 272, 15656-15660.

25. Gupta A Das, Zdunek T, In-vitro lipid peroxidation of human serum catalysed by copper ion: antioxidant rather than prooxidant role of ascorbate, Life Sci, 1992, 50, 2875-2882. 